\title{
What olivine, the neglected mineral, tells us about kimberlite petrogenesis
}

\author{
N. T. Arndt ${ }^{1}$, A. M. Boullier ${ }^{1}$, J. P. Clement ${ }^{1}$, M. Dubois ${ }^{2}$, and D. Schissel ${ }^{3}$ \\ ${ }^{1}$ OSUG, Univ. de Grenoble, BP 53, Grenoble cedex 38401, France \\ ${ }^{2}$ U.F.R. des Sciences de la Terre, UMR 8110 Processus et Bilans des Domaines Sédimentaires, 59655 Villneuve d'Ascq, \\ France \\ ${ }^{3}$ BHP Billiton World Exploration, Inc., 1400-1111 West Georgia Street, Vancouver, B.C. V6E 4M3, Canada
}

Received: 24 April 2006 - Published in eEarth Discuss.: 20 June 2006

Revised: 4 September 2006 - Accepted: 29 September 2006 - Published: 23 October 2006

\begin{abstract}
We report here the results of a petrographic and geochemical study of remarkably well-preserved kimberlites from the Kangamiut region in Greenland. The samples contain between 5 and $45 \%$ of olivine in the form of rounded "nodules", each 1 to $5 \mathrm{~mm}$ in diameter. Most originally were single crystals but many consist of polycrystalline, monomineralic aggregates. Olivine compositions vary widely from nodule to nodule (from Fo 81-93) but are constant within individual nodules. A thin rim of high-Ca olivine of intermediate composition (Fo 87-88) surrounds many nodules. Deformation structures in olivine in the nodules and in the matrix demonstrate a xenocrystic origin for the olivine: only olivine in the thin rims is thought to have crystallized from the kimberlite magma. Using major and trace element data, we show that the kimberlite compositions are controlled by the addition of xenocrystic olivine into a parental magma that contained about 24-28\% MgO.

The monomineralic character of the olivine nodules is problematic because dunite is a relatively rare rock in the lithospheric mantle. The source of the xenocrystic olivine lacked pyroxene and an aluminous phase, which make up about half of most mantle-derived rocks. It appears that these minerals were removed from the material that was to become the nodules, perhaps by fluids that immediately preceded the passage of the kimberlites. We speculate that this mantle "defertilization" process was linked to interaction between $\mathrm{CO}_{2}$ rich fluid and mantle and that this interaction controlled the geochemical and isotopic composition of kimberlites.
\end{abstract}

\section{Introduction}

Kimberlite is a rock dominated by olivine. In most kimberlites, primary textures and mineralogy are poorly preserved,

Correspondence to: N. T. Arndt

(arndt@ujf-grenoble.fr) but rare examples, such as the one shown in Fig. 1, contain $\sim 70 \%$ of fresh olivine set in a matrix of diopside, ilmenite and phlogopite and carbonate. Most previous descriptions of the mineralogy of kimberlite have focused on the latter minerals and surprising little work has been done on the olivine itself. Here we present the results of a petrographic and geochemical investigation of two remarkably preserved kimberlites from Greenland. We demonstrate that the form and composition of the olivine grains is distinctive and peculiar to kimberlite, and then we explore what these features tell us about the origin of kimberlite.

\section{Occurrence of olivine}

Samples NCR 27 and 29 are from a kimberlite dyke sampled in the Kangamiut region on the west coast of Greenland. The dyke has not been dated but probably is upper Proterozoic. Sample NCR 27 is dominated by olivine "nodules", a term we use to indicate that the mineral occurs mainly as single- or multi-grained aggregates with well-rounded outlines. The nodules range from about $<1$ to about $10 \mathrm{~mm}$ and make up about $40 \%$ of the rock. They are sub- to wellrounded (Figs. 1 and 2), and, with the rare exceptions of nodules that contain isolated grains of ortho- or clinopyroxene, they consist entirely of olivine. The olivine in multigranular nodules has two distinctly different morphologies: euhedral tablets (typically 5-3 mm) with well-developed crystal faces, which are imbedded in a matrix of anhedral olivine grains with more variable grain size (5 to $0.3 \mathrm{~mm}$; Fig. 1a). Also present in sample NCR 27 are rare ( $<1$ to $2 \%$ ) megacrysts of ilmenite, phlogopite, orthopyroxene and garnet. The nodules and megacrysts are set in a matrix of small anhedral olivine crystals, phlogopite, Fe-Ti oxides, perovskite, apatite and carbonate. Sample NCR 29 contains about $5 \%$ olivine nodules in matrix similar to that of NCR 27.

Published by Copernicus GmbH on behalf of the European Geosciences Union. 

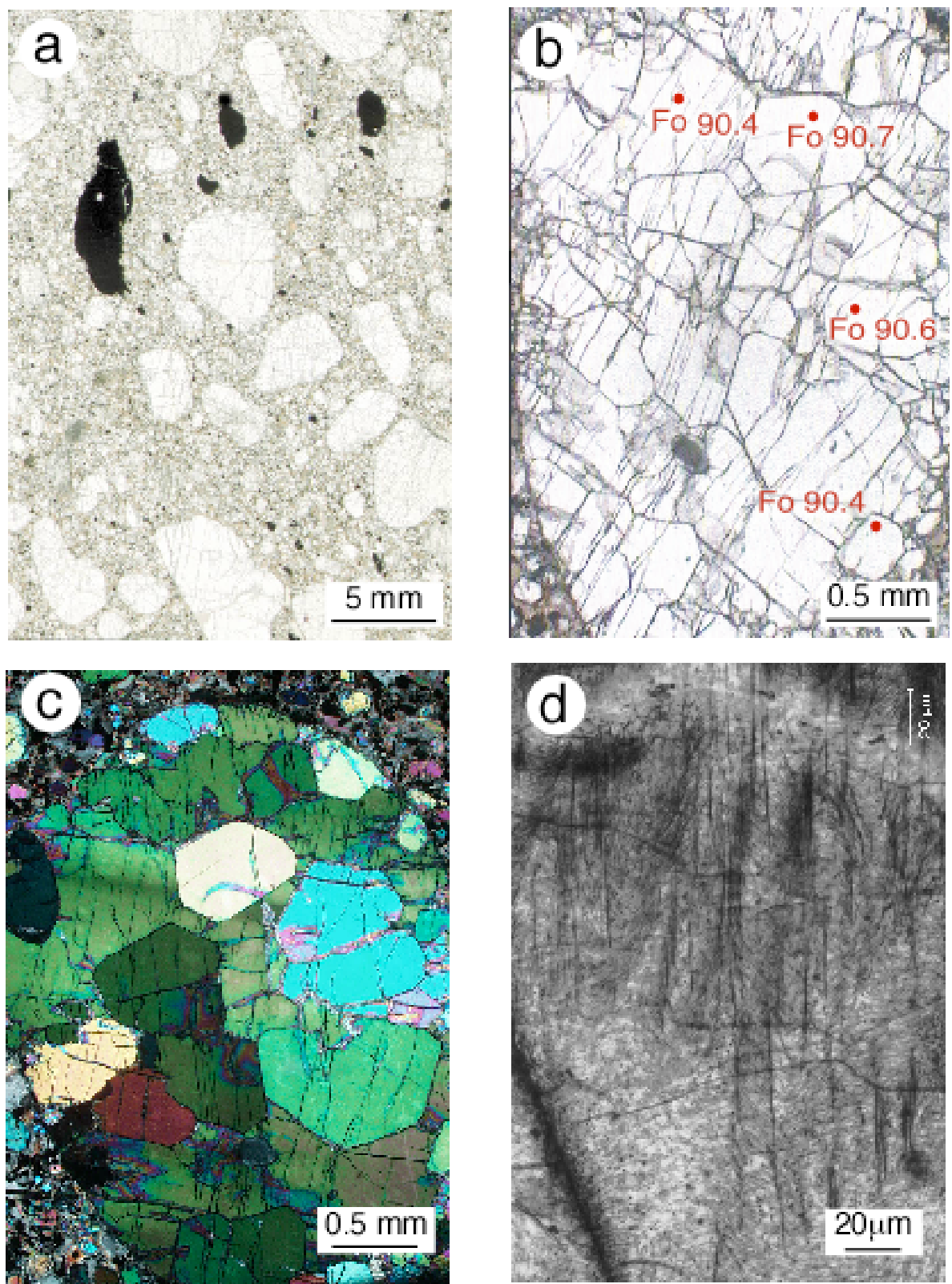

Fig. 1. (a) Scanned thin section. Rounded to subangular olivine nodules and several ilmenite megacrysts in a groundmass of finer-grained olivine, phlogopite, opaques and carbonate. (b) Olivine nodule containing recrystallized euhedral grains in a matrix of deformed olivine. Forsterite contents of measured grains are shown in red. Note the rounded abraded nodule margin at the bottom left. (c) Crossed polars image of the nodule. The euhedral tablets have grown in a matrix comprising at least two deformed olivine crystals. (d) (100) walls (vertical) in an olivine porphyroclast with dislocations extending from one wall to another. The distance $\mathrm{d}$ between walls is relatively small (5 to $10 \mu \mathrm{m})$ and the dislocation density is high.

\section{Deformation features}

The samples were heated in air at $900^{\circ} \mathrm{C}$ for $1 \mathrm{~h}$ to "decorate" the internal structures (Fig. 1d). Anhedral matrix olivine is characterized by undulating extinction and the presence of numerous close-spaced fractures and dislocation walls. The dislocations are arranged in (100) wall structures, secondary
(001) structures, and are oriented roughly perpendicular to the walls. The average distance between the walls is consistent and similar in all the nodules (5 to $10 \mu \mathrm{m}$ ). These features probably result from high stress intracrystalline creep that happened not long before the nodules were incorporated into the kimberlite. The euhedral tabular olivine grains contain fewer dislocations and they are interpreted to have 

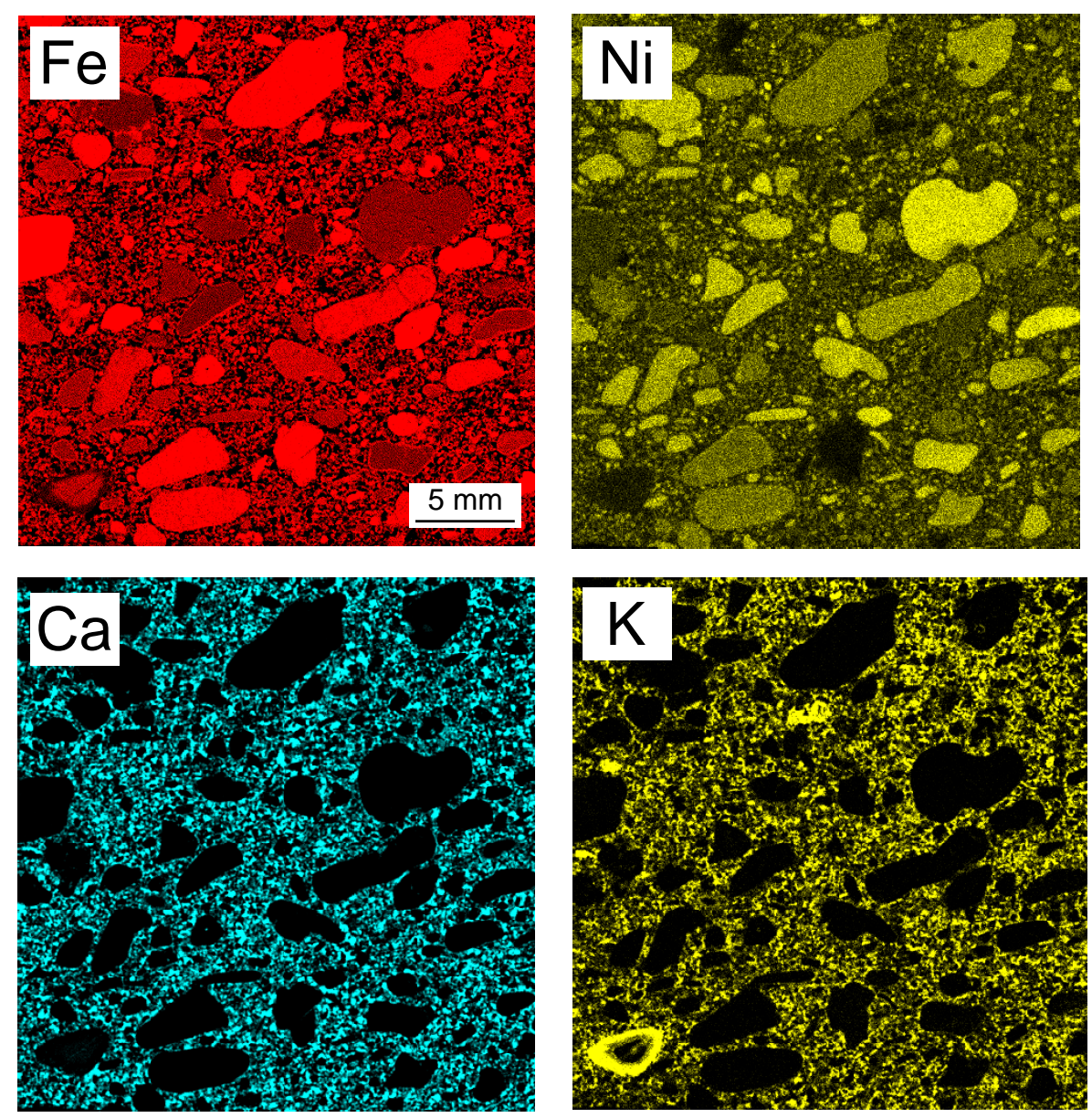

Fig. 2. Scans carried out with the Horiba XGT 5000 X-ray microanalyser showing the distribution of four elements in a portion of sample NCR-27. The outlines of the olivine nodules are most apparent in the Ca image. In the Fe and Ni images, the nodules are seen to have a wide range of compositions: some grains have high $\mathrm{Fe}$ and low $\mathrm{Ni}$; others the inverse. Note too that many olivine nodules are surrounded by thin rims of olivine with constant composition. The phlogopite-rich symplectite rim surrounding a garnet xenocryst is evident in the bottom left of the K image.

grown within the deformed olivine crystals during ascent of the magma, as proposed by Gueguen (1977).

\section{Mineral compositions}

Olivine compositions (Figs. 1b, 2 and 3) are remarkably constant within individual nodules, except for thin outer rims. No differences were observed between grains with different morphologies. The euhedral, undeformed tablets illustrated in Fig. 1c have essentially the same compositions as the large deformed anhedral crystals and small, recrystallized grains. From nodule to nodule, however, the composition varies widely, from $\mathrm{Fo}_{85}$ to $\mathrm{Fo}_{93}$. The least magnesian composition was measured in a large single-crystal nodule; the most magnesian composition in another nodule that contained both euhedral and anhedral grains. Ni contents correlate well with Fo (Fig. 3a). The smaller grains in the matrix have a smaller range of compositions, from $\mathrm{Fo}_{87}$ to $\mathrm{F}_{91}$ in sample NCR 27 and from $\mathrm{Fo}_{83}$ to Fo90 in sample NCR 29.

Most olivine grains or nodules have a very thin $(100-$ $200 \mu \mathrm{m}$ ) outer rim of $\mathrm{Fo}_{87-90}$ in NCR 27 and $\mathrm{Fo}_{84-86}$ in NCR 29. The rims have a far more restricted range of Fo contents than the nodule cores and some nodules show reverse zoning. $\mathrm{CaO}$ contents of most olivine grains are low (Fig. 3b), less than $0.1 \%$, in both nodules and matrix, but the marginal rims have higher $\mathrm{CaO}$ contents, a signature of high-temperature crystallization (Köhler and Brey, 1990).

\section{Interpretation}

The deformation textures, low $\mathrm{CaO}$ contents and wide range of Fo contents suggest that the olivine nodules are xenoliths, presumably fragments from mantle wall rock that were incorporated into the kimberlite magma during its ascent. The 


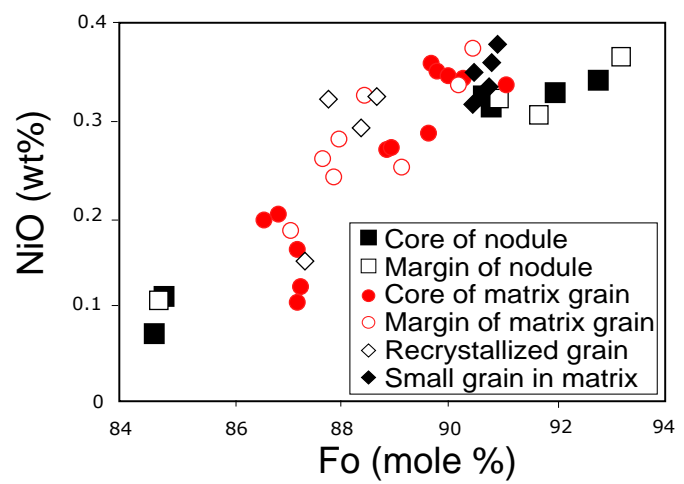

Fig. 3. Compositions of olivines in sample NCR-27.

tabular olivine grains grew by recrystallization, and abrasion produced the rounded outlines of each nodule.

Deformation features in many matrix olivine crystals, and kelyphite rims around orthopyroxene and garnet megacrysts, indicate that they too are xenocrysts. The only phases that crystallized entirely from the kimberlite are phlogopite, perhaps some of the ilmenite, and the fine-grained phases in the groundmass. The fine rims of high-Ca olivine surrounding many nodules have a restricted range in Fo contents. These are probably the only parts of the olivine assemblage that can be assigned a magmatic origin.

\section{Geochemistry}

Selected major elements analyses in our two Greenland samples are plotted together with literature data in Fig. 4. MgO, used as a differentiation index, varies from 25 to $35 \mathrm{wt} \%$. Elements compatible with olivine $(\mathrm{Fe}, \mathrm{Ni})$ plot approximately on olivine control lines but most other elements either scatter widely or define trends that are oblique to such lines.

\section{Composition of kimberlite liquid}

The presence of abundant xenocrystic olivine makes it likely that each sample contains more olivine than would have crystallized directly from the parental silicate liquid. This applies even to the aphanitic sample NCR-29, which is essentially free of olivine "macrocrysts" (or nodules) but contains abundant olivine in its matrix.

To estimate the composition of the silicate liquid, we used the composition of the thin rims of high-Ca olivine and the $\mathrm{MgO}$ and $\mathrm{FeO}$ contents of the whole rocks, as shown in Fig. 4. From the composition of the most magnesian rims, $\mathrm{Fo}_{88}$, we calculate the $\mathrm{MgO} / \mathrm{FeO}$ of the olivine, and using Dalton and Wood's (1993) distribution coefficient $\left(\mathrm{KD}_{\mathrm{MgO}-\mathrm{FeO}}=0.51\right.$ to 0.66$)$, we calculate the $\mathrm{MgO} / \mathrm{FeO}$ of liquid in equilibrium with this olivine. In Fig. 4e, the aphanitic Greenland kimberlite NCR29 plots between the

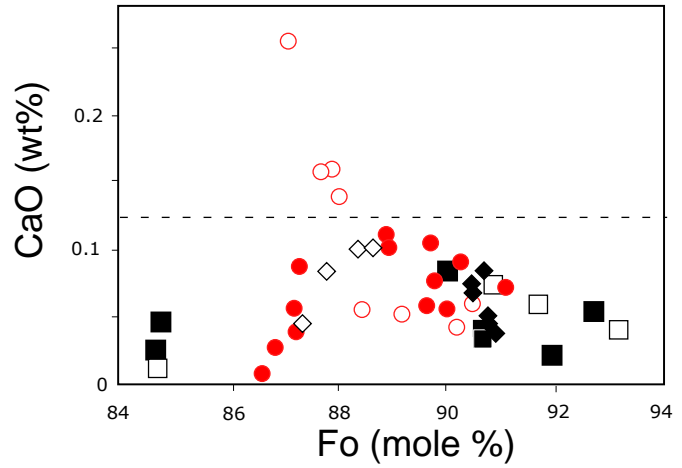

lines corresponding to liquids calculated using the two partition coefficients, indicating that its bulk composition approximates that of the liquid. The exact $\mathrm{MgO}$ content cannot be estimated from our limited sample suite, but if the liquid contained about $10-11 \% \mathrm{FeO}$, like the Greenland samples, its $\mathrm{MgO}$ would be around 24-28\%. Sample NCR27, on the other hand, plots to the right of the lines indicating that it contains excess olivine.

\section{Interpretation of the chemical data}

Price et al. (2000) proposed that an aphanitic kimberlite from the Jericho pipe in Canada provides an estimate of the composition of "primitive", unfractionated, kimberlite magma. Le Roex et al. (2003) use an inflection in major element trends at the limit between the compositions of aphanitic and macrocryst-rich kimberlites to estimate the primitive liquid composition. Our estimate of the $\mathrm{MgO}$ content of the kimberlite liquid is similar to that of the Jericho aphanitic kimberlites, but lower than the $\mathrm{MgO}$ content in Price et al.'s "primitive" kimberlites. These differences are due, at least in part, to excess olivine in the latter samples, either macrocrysts or excess groundmass olivine.

\section{Discussion}

Judging from our study of samples from other regions and literature descriptions, olivine nodules of the type shown in Fig. 1 are present in many kimberlites. The origin of these nodules is enigmatic, but, we believe, highly important in the context of kimberlite petrogenesis. Most remarkable is their essentially monomineralic character and dunitic composition, combined with their wide range in Fo contents (Fig. 1). In suites of kimberlite- or basalt-borne mantle xenoliths, dunite is not common, and most samples contain abundant pyroxene and spinel or garnet. In most mantle xenoliths, olivine makes up less than $60 \%$ of the mineral assemblage. 

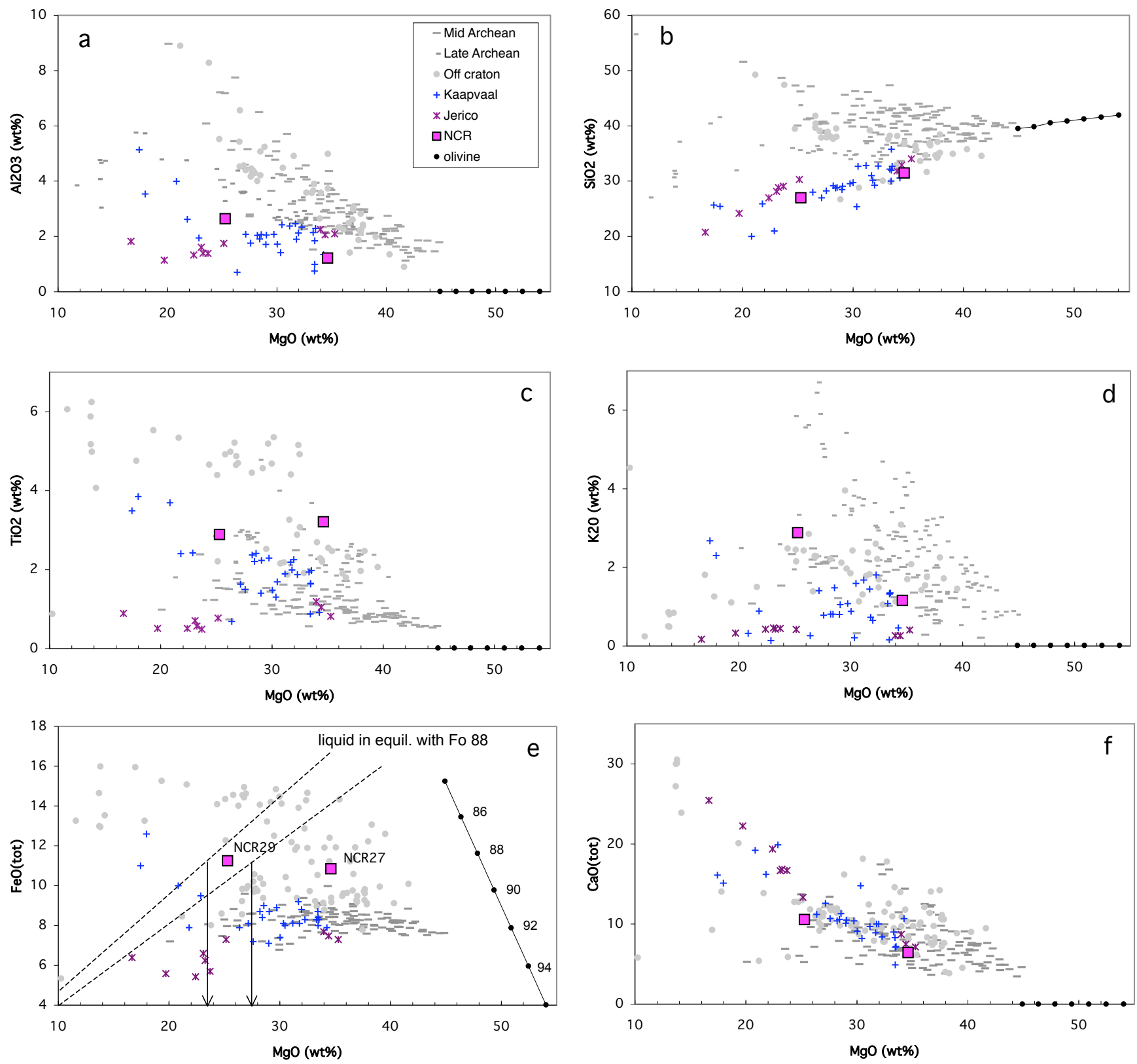

Fig. 4. Comparison between the compositions of the studied samples and those of other kimberlites. The dashed lines in the $\mathrm{MgO}$ vs. FeO diagram indicates the compositions of liquids in equilibrium with $\mathrm{Fo}_{88}$; the upper for a distribution coefficient of 0.51 , the lower for 0.66 (Dalton and Wood, 1993). Many kimberlites lie between these lines and the olivine compositions indicating that they contain excess olivine. Note the following features: (1) the large variations in the concentrations of certain elements. At $20 \% \mathrm{MgO}_{,} \mathrm{Al}_{2} \mathrm{O}_{3}$ varies from 1 to $9 \%$, $\mathrm{TiO}_{2}$ from 0.5 to $5.5 \%$ and $\mathrm{FeO}$ (tot) from 5 to $16 \%$; (2) In most diagrams the data plot in a fan-shaped field converging on the olivine compositions. This indicates that the accumulation and fractionation of olivine has a major control on kimberlite compositions. Sources of data: Jericho - Price et al. (2000); Kaapvaal - Le Roex et al. (2003); Archean and off-craton kimberlites - compiled data provided by C. Smith of De Beers. The olivine compositions are calculated from stoichiometry.

Bernstein et al. (1998) have reported xenoliths from east Greenland that contain an unusually high proportion of olivine, from 70 to $>95 \%$, but this olivine is distinguished by a very uniform, forsterite-rich composition, averaging Fo92.7. These authors interpret the xenoliths as the refractory residue left after extraction of a large amount of partial melt.
In the Greenland kimberlites, olivine is the sole constituent of the vast majority of nodules in kimberlites. Orthopyroxene and garnet are present but rare, and their kelyphite margins indicate they were out of equilibrium with the kimberlite magma. In contrast, we can deduce from the high-Ca rims that olivine was a liquidus phase that crystallized from the 
kimberlite magma. And in contrast to the uniform, forsteriterich composition of the depleted xenoliths from east Greenland, the nodules in the kimberlites have a vast range of forsterite contents, from $\mathrm{FO}_{93}$ to as low as $\mathrm{Fo}_{81}$. We conclude therefore that this olivine did not form as the residue of melt extraction.

It appears instead that an unknown process extracted all minerals other than olivine from the material that was to form the nodules. This process acted before the passage of the kimberlite magma itself, or at least before the nodules were abraded to their rounded form. The process preceded, or was synchronous with, the deformation recorded by the dislocation structures. The processes resulted in the crystallization of olivine that had a wide range of olivine compositions that is far greater - extending to lower Fo contents than that commonly recorded in normal peridotites from the lithosphere.

Independent evidence for the process, which could be described as mantle "defertilization", was presented by Arndt (2003) who attributed the high $\mathrm{MgO}$ contents in a global suite of kimberlites to the addition of olivine alone, without the addition of orthopyroxene and other minerals that should have been present in xenoliths from the lithospheric mantle.

The exact nature of the defertilization process is enigmatic. It may represent some type of metasomatism, due perhaps to the influx of $\mathrm{CO}_{2}$-rich fluids. However, rather than enriching the invaded rocks in incompatible elements and fluids - the role normally assigned to metasomatising agents - these fluids extracted the low-temperature components from the rock, leaving behind olivine, the most refractory mineral. A process that fits this behaviour is the interaction envisaged by Kelemen (1990) between hydrous fluids and peridotite above subduction zones, or by Khazan and Fialko's (2005) diffusive interaction between the mantle and upward migrating kimberlite magma.

We speculate that a comparable process may have affected the material incorporated as olivine nodules into the kimberlites. A strongly $\mathrm{Si}$-undersaturated, $\mathrm{CO}_{2}$-rich magma could have reacted with and assimilated pyroxene and garnet, leaving behind only olivine. This process could have taken place below or within the lithosphere, and the fluids involved could have been parental to the kimberlites. Such interaction probably controlled the trace-element contents of kimberlites, as proposed by Khazan and Fialko (2005). If the interaction took place entirely at sub-lithosphere depths, the kimberlite will acquire an asthenospheric isotopic signature; if it continued into the lithosphere, the isotopic signature will reflect this interaction. The $\mathrm{CO}_{2}$ content of the parental magma might control the depth interval over which such interaction takes place and influence the isotopic compositions of kimberlites (see Becker and Le Roex, 2006) for a recent summary of the isotopic compositions of kimberlites). In Group I kimberlites, which have asthenospheric isotopic signature and high $\mathrm{CO}_{2}$ contents, exsolution might start at depths near the base of the lithosphere driving the magma rapidly to the surface and precluding subsequent interaction with the wall rocks. These magmas retain the isotopic signature of the asthenosphere. In Group II kimberlites, which generally have lower $\mathrm{CO}_{2}$ contents, exsolution will take place at shallower depths, the magma will interact with the shallower mantle and acquire the lithospheric isotopic signature that characterizes this type of kimberlite.

\section{Conclusions and implications}

This model is relevant not only to kimberlite petrogenesis but also has economic implications. The source of the diamonds that are found in kimberlites is the mantle through which the kimberlite passed on its way towards the surface, most probably the lithospheric mantle. The diamonds may therefore have been present in the "defertilized" material processed from peridotite to dunite. If this is so, the incorporation of diamond into kimberlite will depend on the nature of the reprocessing and the manner in which the reprocessed material is incorporated into the kimberlite.

\section{Appendix A}

\section{Analytical methods}

Major element concentrations were determined at the Service d'Analyses of the Centre de Recherche Petrographique et Geochimique (CRPG) in Nancy, France. Details of the analytical procedure and estimated precision and accuracy are found at http://www.crpg.cnrs-nancy.fr/SARM/index.html. Olivine compositions were measured at Université BlaisePascal, Clermont-Ferrand, using standard techniques.

Edited by: A. Sobolev

\section{References}

Arndt, N. T.: Komatiites, kimberlites and boninites, J. Geophys. Res., 108(B6), 2293, doi:10.1029/2002JB002157, 2003.

Becker, M. and Le Roex, A.: Geochemistry of South African onand off-craton, group I and group II kimberlites: petrogenesis and source region evolution, J. Petrol., 47, 673-703, 2006.

Bernstein, S., Kelemen, P. B., and Brooks, C. K.: Depleted spinel harzburgite xenoliths in Tertiary dykes from East Greenland: Restites from high degree melting, Earth Planet. Sci. Lett., 154, 221-235, 1998.

Dalton, J. A. and Wood, B. J.: The partitioning of Fe and Mg between olivine and carbonate and the stability of carbonate under mantle conditions, Contrib. Mineral. Petrol., 114, 501-509, 1993.

Guéguen, Y.: Dislocations in mantle peridotite nodules, Tectonophysics, 39, 231-254, 1977.

Kelemen, P. B.: Reaction between ultramafic wall rock and fractionating basaltic magma: Part I, Phase relations, the origin of calc- 
alkaline magma series, and the formation of discordant dunite, J. Petrol., 31, 51-98, 1990.

Khazan, Y. and Fialko, Y.: Why do kimberlites from different provinces have similar trace element patterns?, Geochem. Geophys. Geosyst., 6, Q10002, doi:10.1029/2005GC000919, 2005.

Köhler, T. P. and Brey, G. P.: Calcium exchange between olivine and clinopyroxene calibrated as a geothermobarometer for natural peridotites from 2 to $60 \mathrm{~kb}$ with applications, Geochim. Cosmochim. Acta, 54, 2375-2388, 1990.
Le Roex, A. P., Bell, D. R., and Davis, P.: Petrogenesis of group I kimberlites from Kimberley, South Africa: Evidence from bulkrock geochemistry, J. Petrol., 44, 2261-2286, 2003.

Price, S. E., Russell, J. K., and Kopylova, M. G.: Primitive magma from the Jericho Pipe, N.W.T., Canada: Constraints on primary kimberlite melt chemistry, J. Petrol., 41, 789-808, 2000. 